\title{
A Summary of Current Research on the Functional Morphology of Flight in Azhdarchid Pterosaurs
}

\author{
Amy Klein, Curtis W. Anderson* \\ Department of Biological Sciences, Idaho State University, Pocatello, Idaho, 83209, USA
}

dai: https://doi.org/10.21467/ajgr.3.1.9-12

*Corresponding Author email: andecurt@isu.edu

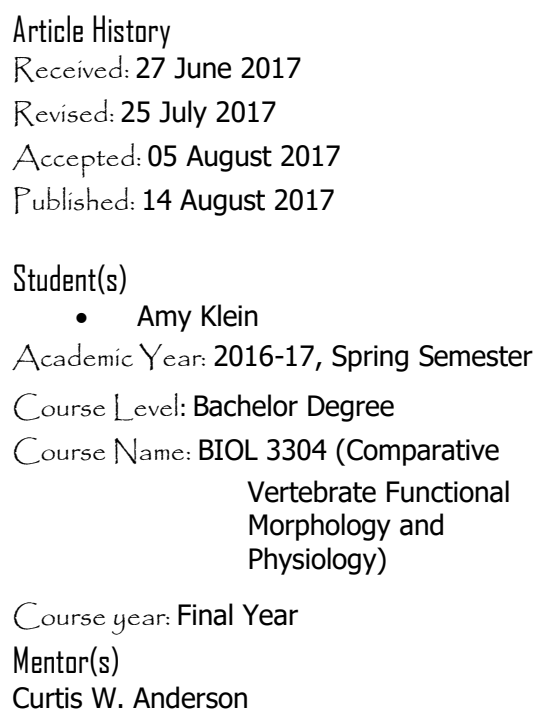

\begin{abstract}
Azhdarchid pterosaurs existed during the Mesozoic era and died out during the mass extinction at the end of the Cretaceous. These amazingly large creatures have sparked a debate on whether they were capable of flying or simply gliding due to their massive size, anatomy and morphology. Two theories that have been developed are that these creatures were terrestrial stalkers and that they are closer to pelicans in terms of feeding capability. More specifically, Naish and Witton suggest that these giants were capable of covering large distances by soaring and could forage on land by walking quadrupedally using their long necks to reach down and kill small animals, consume dead tissues and possibly fruits. Fossil evidence to support this theory includes tracks of the Azhdarchid's showing a parasagittal gait, a winged planform, and specimens have been only found in continental depositional settings. Evidence also indicates that these creatures had membranes serving as wings, but it cannot be discerned with current knowledge whether membranes were used for gliding or for true flying.
\end{abstract}

Keywords: pterosaurs, evolution of flight, functional morphology

\section{Introduction}

In 1840, John Phillips invented the term Mesozoic, which means "Middle Animal". The Mesozoic Era was a geological time period that lasted 180 million years and is composed of three smaller time periods, Triassic, Jurassic and the Cretaceous. The cretaceous period lasted 81 million years, which during that time there was a continual rule of dinosaurs and other reptiles, the start of flowering plants and other giant organisms. Most of the giants perished in the most famous mass extinction that occurred 65 million years ago at the end of the Cretaceous period. One particular group of giant creatures has stirred some debate recently, the Azhdarchid pterosaurs. The debate is whether they were terrestrial stalkers in terms of catching food and also if they were capable of true flight or just simple gliding. 


\section{Review and Discussion}

Azhdarchid pterosaurs are depicted as large terrestrial animals with long necks, long-billed, toothless and short-winged creatures that have been imagined as many things such as "mega-skimmers, heron-like waders, obligate scavengers of dinosaur carcasses, and even as sandpiper-like littoral foragers" [1]. According to Naish, all of those depictions are inconsistent with the anatomical features of these pterosaurs. Naish and Witton have hypothesized that these giants were actually terrestrial stalkers and were capable of covering large distances by soaring, could forage on land by walking quadrupedally using their long necks to reach down and grab small animals, parts of dead tissues, and possibly fruits [1], [2]. Evidence to support this theory is that there is fossil evidence of tracks of the Azhdarchid's showing a "parasagittal gait" [3], a winged planform (meaning the shape of the wing, which would help with flying over land rather than water), and from data indicating that all Azhdarchid fossils are found in "continental depositional setting." [3]. Scientists have been hypothesizing a living analogue to the Azhdarchids but there is no scientific evidence of a true living relative. Current theories due to the terrestrial stalker hypothesis would be modern ground hornbills or the Marabou Stork [1]. This is also based on their anatomy of "robust hindlimb elements" [2]. Others think that they are more closely related to pelicans or vultures due to the evidence of the neck anatomy found in the fossil record [4].

Another debate concerning these giant creatures was that of their habitat. Some scientists believe that they stayed closely to aquatic habitats because that is where many of the fossils are discovered. In 2015, Naish and Witton hypothesized that while it seems that some of the fossil record we have of these pterosaurs does in fact come from aquatic sediments, so do many other terrestrial and aquatic creatures. However, there is "no more paleoecological significance to their frequent recovery from lake, stream, and floodplain deposits than there is for the fossils of the undoubted terrestrial species" [2]. Additionally, Averianov [4] hypothesizes that the richness of young Azhdarchids in the fluvial beds of Uzbekistan suggests that they were used perhaps as a nesting area in close proximity of a large river, which refutes the notion of them having a wetland mode of life.

It had been proposed that the Azhdarchids actually are more closely related to modern day skimmers or pelican type animals. Evidence for this theory was based upon the reconstruction of the neck anatomy of the Azhdarchids [4], [5]. The theory is that their extremely long neck is what set them apart from other pterosaurs. Their cervical vertebrae are very similar to those of other pterodactyloids, but cervical vertebrae 4 and 5 are distinctly different. These two vertebrae are elongated which then allows them to become more cylindrical in nature due to the fusion of the centrum and neural archway and due to the reduction of the neural spines [4]. The vertebrae of the Azhdarchids tend to be lengthened and are strongly procoelous with neural spines that are low, ridge-like, with virtually no transverse processes [2]. In addition to these characteristics, the cervical vertebra usually had large zygapophyses and postzygapophyses that are posteroventrally positioned on the articular surface with the opposite faces on the prezygapophyses [2]. But would those elongated necks be helpful or a hindrance in terms of feeding?

Nessov proposed that Azhdarchids were icthyophagous or simply skimmers. His evidence to support this was based upon that the "long neck allowed them to fly for a long time at a constant altitude above water, touching the water with the tips of closed jaws and retaining the body far from its surface" [4]. This must have meant that Azhdarchids had a throat sac, which can be supported by the evidence of a spiral joint (a hinged type joint where the raised and divots on opposite articular surfaces make up part of a spiral, where flexion is assisted by a particular quantity of lateral deviation) but has not been confirmed by the fossil record. Pelicans also have a spiral joint, which then allows for the throat sac, which makes way for the "scoop net" method of catching food such as fish. Azhdarchids's mouths are thought to have weak masticatory muscles and slender forcep-like jaws that are thought to mean they would feed on small, slow moving or possible immobile creatures. Other evidence in the fossil record shows that they had a winged membrane much like a bat [6]. 
Perhaps the biggest question or debate about the Azhdarchids pterosaurs is whether they were capable of true flight or were they only able to glide. There is scientific evidence within the fossil record that shows that they had a membranous wing that was attached from the front limbs to the hind limbs. For it to be able to attach it would have had to been short and wide due to the fact that their hind limbs were very long and their forelimbs were quite short. These particular pterosaurs had an extremely short fourth phalanx within the wing digit, which contributed to their short forelimbs [4]. Thus, the forelimb-hindlimb ratio of the Azhdarchids is relatively low [2]. This suggests they would in fact have a low wing, which leads scientists to the theory that they were possibly static soarers who used the warming air and thermals to help change their altitudes [2]. Due to their short yet broad wings, they would have been able to take off in vegetated inland areas which is partially confirmed by the often occurrences of their fossils being discovered in terrestrial strata. Their membranous wings were not their only problem to overcome to fly; another big issue was how large they were. Estimated body mass is from $70 \mathrm{~kg}$ to up to $250 \mathrm{~kg}$. Creatures with large body mass obviously have much more to get off the ground when it comes to flying. Birds and bats have common attributes of flight that can be seen and compared, so one would expect a potential similar situation for pterosaurs since they have a membranous wing. However, if we look at strictly biomechanical results we see that the aspects of launching dynamics, flapping dynamics and morphological scaling are not equivalent between pterosaurs and birds [7]. Due to this, one should not take the mechanical limits as equivalent between the two groups. Thus, these pterosaur wings were profoundly different from that of the avian group in the fact that they were membranous and thought to be attached to the back leg. Additionally, the rate of flapping does not change with mass or wingspan but weight, span, area of the wing and the muscle fractions can all impact the flapping rate [7]. Their wing platform shows evidence that leads some to believe that they were capable of slow, soaring flight and to others fast, dynamic flying. Witton and Naish [2] have estimated roughly 90-120 seconds of powered, anaerobic flight from one burst. Unfortunately there is a lack in research when it comes to the functional morphology of the Azhdarchid family.

Since the membrane of the wing was attached to the hind limb it is assumed that these pterosaurs walked quadrupedially. Fossil record shows that most pterosaur tracks are quadrupedal. "This implies that quadrupedality was the rule within Pterosauria, and that the group inherited quadrupediality from their common ancestor or evolved a quadrupedal stance early in their evolution" [7]. So when it comes to the overall size of the animal the mechanical limits are dependent on the smaller details of morphology rather than the larger locomotion classifications and the critical traits of form that release the limits of size tend to be genetically obtained from their ancestors, which means that it's a matter of phylogenetic chance [7].

\section{Conclusions}

The evidence indicating that these creatures had membranes that allowed their arms to be winged, so to speak, has brought up controversy on whether or not they were capable of flying. The evidence within the fossil record indicates that the membrane did exist however it is hard to know discern if it was used simply for gliding or for true flying. There is evidence that supports both theories but still not confirmed due to the limited knowledge that is known about these giant creatures. It's also difficult to simulate flight on the Azhdarchids because there is a lack of corresponding sized extant analogues. What is known is that their environment, feeding habits, abnormal anatomy of their neck and body, membranous wings and their biomechanics needs to be considered when it comes to the flying debate.

\section{Acknowledgment}

The authors would like to thank the Department of Biological Sciences at Idaho State University. This review is a result of efforts in BIOL 3304, 'Comparative Vertebrate Functional Morphology and Physiology'. 


\section{How to cite this article:}

Klein, A., \& Anderson, C. (2017). A Summary of Current Research on the Functional Morphology of Flight in Azhdarchid Pterosaurs. Advanced Journal Of Graduate Research, 3(1), 9-12. doi: https://doi.org/10.21467/ajgr.3.1.9-12

\section{References}

[1] Darren; Naish, "Were azhdarchid pterosaurs really terrestrial stalkers? The evidence says yes, yes they (probably) were," Blog Post, 15-Dec-2013. [Online]. Available: https://blogs.scientificamerican.com/tetrapod-zoology/were-azhdarchid-pterosaurs-reallyterrestrial-stalkers-the-evidence-says-yes-yes-they-probably-were/. [Accessed: 13-Aug-2017].

[2] M. P. Witton, D. Naish, H. Otsuka, D. Unwin, and L. Maas, "A Reappraisal of Azhdarchid Pterosaur Functional Morphology and Paleoecology,” PLoS One, vol. 3, no. 5, p. e2271, May 2008.

[3] M. Witton and D. Naish, “Azhdarchid pterosaurs: water-trawling pelican mimics or 'terrestrial stalkers'?," Acta Palaeontol. Pol., vol 60, no 3, pp 651-660, 2015.

[4] A. O. Averianov, "Reconstruction of the neck of Azhdarcho lancicollis and lifestyle of azhdarchids (Pterosauria, Azhdarchidae)," Paleontol. J., vol. 47, no. 2, pp. 203-209, Mar. 2013.

[5] L. A. Nessov, "Giant flying reptiles of the family Azhdarchidae. I. Morphology, systematics," Vestn. Leningr. Univ., vol. 7, no. 2, pp. 14-23, 1991.

[6] Witton and Naish, "Figure 1," 2013. [Online]. Available: http://2.bp.blogspot.com/-vUu-

WFwLDf8/Um7IKqMXqvI/AAAAAAAAA5A/IkUVjEi82s8/s1600/Witton+and+Naish+2013+Fig.+1.jpg. [Accessed: 13-Aug2017].

[7] M. Habib, "Constraining the Air Giants: Limits on Size in Flying Animals as an Example of Constraint-Based Biomechanical Theories of Form," Biol. Theory, vol. 8, no. 3, pp. 245-252, Sep. 2013.

\section{Publish your research article in AIJR journals-}

$\checkmark \quad$ Online Submission and Tracking

$\checkmark$ Peer Reviewed

$\checkmark$ Rapid decision

$\checkmark$ Immediate Publication after acceptance

$\checkmark$ Open Access (Articles freely available online)

$\checkmark$ Retain full copyright of your article.

Submit your article at journals.aijr.in 